\title{
C-Raf antagonizes apoptosis induced by IFN- $\alpha$ in human lung cancer cells by phosphorylation and increase of the intracellular content of elongation factor $1 \mathrm{~A}$
}

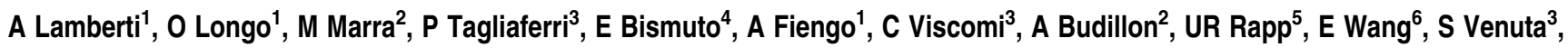 \\ A Abbruzzese ${ }^{*, 4}, P$ Arcari ${ }^{*, 1,7}$ and M Caraglia ${ }^{\star, 2}$
}

Interferon $\alpha$ (IFN $\alpha$ ) induces both apoptosis and a counteracting epidermal growth factor Erk-dependent survival response in cancer cells. In this report, IFN $\alpha$ increased eukaryotic elongation factor 1A (eEF-1A) protein expression by inhibition of eEF-1A degradation via a proteasome-dependent pathway. The reduction of the expression level of eEF-1A by RNA interference enhanced the apoptosis induced by IFN $\alpha$ on the same cells. Moreover, IFN $\alpha$ induced the phosphorylation of both serine and threonine in eEF-1A. These effects were paralleled by an increased co-immunoprecipitation and colocalization of eEF-1A with C-Raf. The suppression of C-Raf kinase activity with the inhibitor BAY 43-9006 completely antagonized the increase of both eEF$1 \mathrm{~A}$ phosphorylation and expression and of C-Raf/eEF-1A colocalization induced by IFN $\alpha$ and enhanced apoptosis and eEF-1A ubiquitination. Cell transfection with the mutated K48R ubiquitin increased EF-1A expression and desensitized tumor cells to the modulating effects of IFN $\alpha$. The dynamic simulation of 3Dstructure of eEF-1A identified putative serine and threonine phosphorylation sites. In conclusion, the interaction between eEF-1A and C-Raf increases eEF-1A stability and induces a survival activity.

Cell Death and Differentiation (2007) 14, 952-962. doi:10.1038/sj.cdd.4402102; published online 2 March 2007

In the past years, much attention has been directed to the study of the genetic information and alterations that regulate eukaryotic cell proliferation and lead to neoplastic transformation. However, an increasing body of data emerges on the involvement of translational machinery in control of both cell proliferation and apoptosis. ${ }^{1-3}$

The eukaryotic translation elongation factor $1 \mathrm{~A}(\mathrm{eEF}-1 \mathrm{~A})$ catalyzes the first step of the protein synthesis elongation cycle. ${ }^{4,5}$ Two isoforms of the protein that are encoded by two different genes, eEF-1A1 and eEF-1A2 are known and they are expressed in a tissue specific manner. ${ }^{6-9}$ Besides its central role in translation, eEF-1A is involved in several cellular processes. ${ }^{10,11}$ Recently, it has been shown that eEF$1 \mathrm{~A} 1$ isoform seems to play a pro-apoptotic role in erythroleukemic $^{11,12}$ and cardiomyocyte cell lines, ${ }^{13,14}$ whereas eEF$1 \mathrm{~A} 2$ isoform appears to protect from apoptosis differentiated myotubes in skeletal muscle ${ }^{15}$ and hematopoietic cells. ${ }^{16}$ Moreover, eEF-1A2 is an important ovarian oncogene that activates tumorigenesis and inhibits apoptosis. ${ }^{17}$ Therefore, to perform further studies on the possible role of eEF-1A in the regulation of apoptosis in cancer cells gains interest. As experimental model we have chosen the human epidermoid lung cancer $\mathrm{H} 1355$ cells in which apoptosis induced by interferon $\alpha$ (IFN $\alpha$ ) is well characterized. ${ }^{18}$ Moreover, in these cells IFN $\alpha$ triggers an important survival mechanism mediated by an epidermal growth factor (EGF)-Ras-mitogen activated protein kinase-dependent cascade. ${ }^{19}$ The specific inhibition of this pathway potentiates the apoptosis induced by IFN $\alpha$ in epidermoid cancer cell lines. ${ }^{20-22}$ However, the mechanisms by which this signal transduction pathway antagonizes the pro-apoptotic effects of IFN $\alpha$ are presently unknown.

On the basis of these findings, changes of eEF-1A intracellular levels in $\mathrm{H} 1355$ cells exposed to IFN $\alpha$ were analyzed. The role of eEF-1A in the apoptosis induced by IFN $\alpha$ was evaluated by reducing the intracellular content of eEF-1A through small interfering RNA (siRNA). We also found

\footnotetext{
${ }^{1}$ Department of Biochemistry and Medical Biotechnology, 'Federico II' University of Naples, Naples, Italy; ${ }^{2}$ Department of Experimental Oncology, Experimental Pharmacology Unit, National Institute of Tumours 'Fondaz. G Pascale' of Naples, Naples, Italy; ${ }^{3}$ Department of Experimental and Clinical Medicine, University Magna Graecia of Catanzaro, Catanzaro, Italy; ${ }^{4}$ Department of Biochemistry and Biophysics, Second University of Naples, Naples, Italy; ${ }^{5}$ Department of Cell Research, Institute of Medical Radiation and Cell Research (MSZ), University of Würzburg, Würzburg, Germany; ${ }^{6}$ Department of Biochemistry and Molecular Biology, University of Louisville School of Medicine, Louisville, KY, USA and ${ }^{7}$ CEINGE, Advanced Biotechnology scarl, Naples, Italy

${ }^{*}$ Corresponding authors: A Abbruzzese, Department of Biochemistry and Biophysics, Second University of Naples, Via Costantinopoli, 1680138 , Naples, Italy. Tel: + 39081 5665871; Fax: + 39081 5665863; E-mail: alberto.abbruzzese@ @nina2.it or M Caraglia, Department of Experimental Oncology, Experimental Pharmacology Unit, National Institute of Tumours 'Fondaz. G Pascale' of Naples, Via Mariano Semmola, 80131 Naples, Italy. Tel: +390815903595 ;

Fax: + 39081 5903813; E-mail: michele.caraglia @ fondazionepascale.it or P Arcari, Department of Biochemistry and Medical Biotechnology, 'Federico II' University of Naples, Via S Pansini, 580131 Naples, Italy. Tel: + 39081 7463120; Fax: + 39081 7463653; E-mail: arcari@ dbbm.unina.3

Keywords: C-Raf; EF-1A; IFN $\alpha$; apoptosis; proteasome; epidermoid cancer cells

Abbreviations: eEF-1A, eukaryotic elongation factor 1A; EGF, epidermal growth factor; EGF-R, epidermal growth factor receptor; FBS, fetal bovine serum; GAPDH, glyceraldehyde-3-phosphate dehydrogenase; IFN $\alpha$, interferon $\alpha$; IU, international unit; mAb, monoclonal antibody; MAPK, mitogen activated protein kinase; siRNA, small interfering RNA

Received 23.5.06; revised 14.11.06; accepted 04.12.06; Edited by RA Knight; published online 02.3.07
} 
that IFN $\alpha$ increased eEF-1A phosphorylation in both serine and threonine residues and decreased its proteasomedependent degradation. On the basis of these data and on the hyperactivation of the IFN $\alpha$-induced EGF $\rightarrow$ ras $\rightarrow$ C-Raf $\rightarrow$ Erk-dependent pathway, we have studied the molecular interaction between eEF-1A and C-Raf in H1355 cells. Moreover, it was evaluated if C-Raf could be directly responsible for post-translational modifications of eEF-1A, thus leading to its intracellular stabilization.

\section{Results}

Effect of IFN $\alpha$ on the expression of eEF-1A in $\mathrm{H} 1355$ cells. The intracellular content of eEF-1A protein and the expression of eEF-1A mRNA in $\mathrm{H} 1355$ cells were evaluated at different times after treatment with $2500 \mathrm{IU} / \mathrm{ml}$ IFN $\alpha$. The intracellular levels of eEF-1A increased about twofold after 10 min of treatment with IFN $\alpha$, as evaluated by immunoblot assay, and its levels remained increased until $60 \mathrm{~min}$, and returned to basal levels at $180 \mathrm{~min}$ (Figure 1a and b). Northern blot analysis of total RNA extracted from $\mathrm{H} 1355$ cells did not show changes in eEF-1A mRNA levels, when compared to the expression of glyceraldehyde-3-phosphate dehydrogenase (GAPDH) mRNA (Figure 1c and d). Similar results were obtained on human epidermoid head and neck cancer KB cell line (data not shown). The expression of the two isoforms of eEF-1A was also studied, and it was found that the expression of both isoforms was increased by treatment with IFN $\alpha$ (Figure 1e and f). In fact, eEF-1A1 was about 0.5 -fold increased after $30 \mathrm{~min}$ of exposure to the cytokine, whereas no change was recorded after $10 \mathrm{~min}$

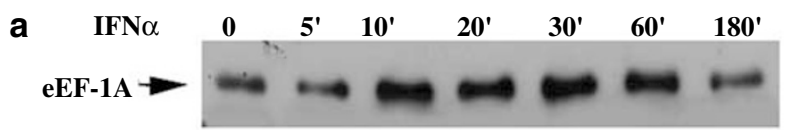

$\beta$-actin

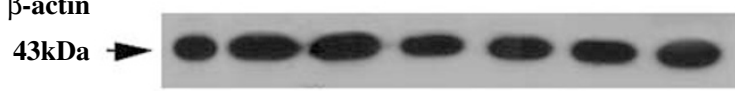

b
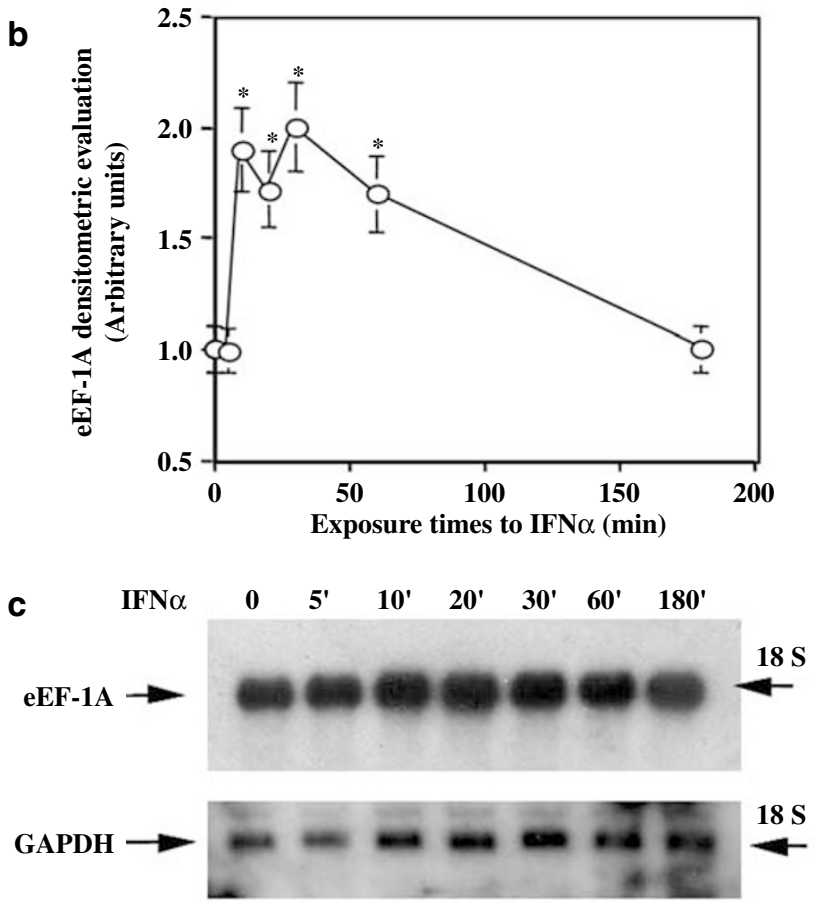

d
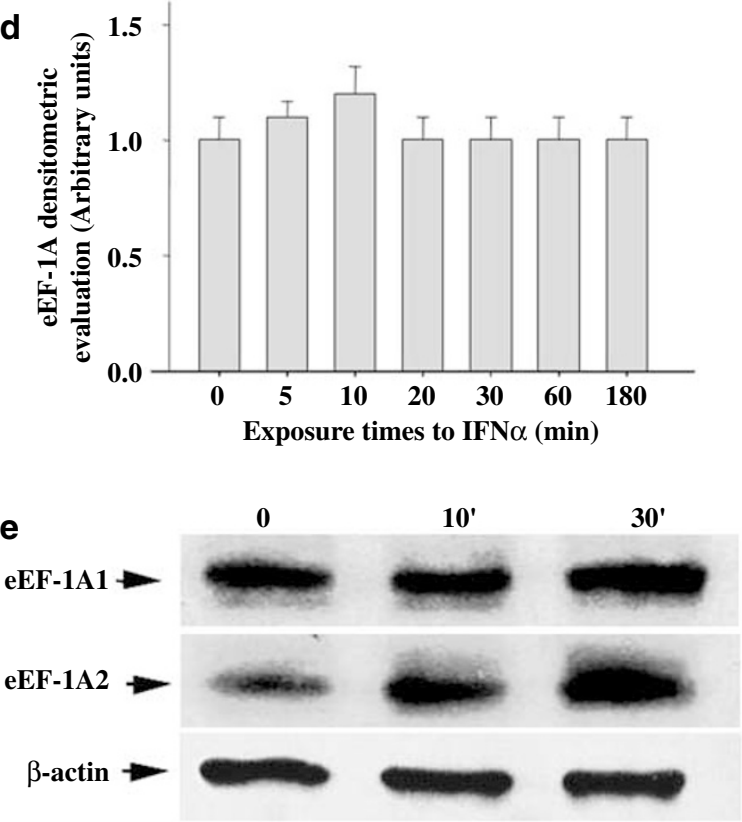

f

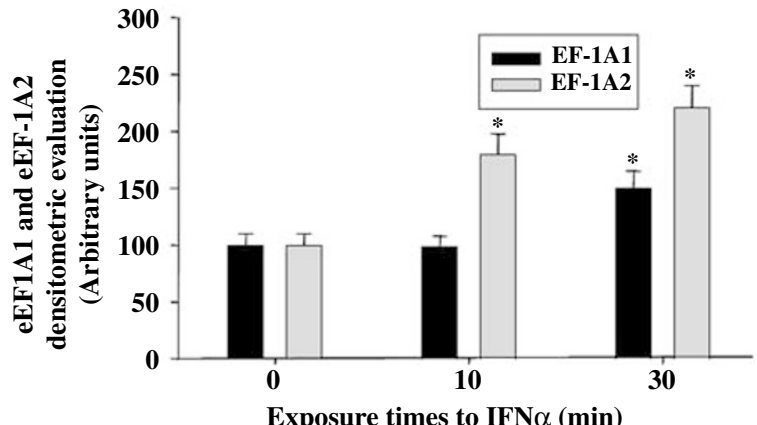

Figure 1 Expression of eEF-1A in H1355 cells after IFN $\alpha$ treatment. (a) Immunoblotting analysis of eEF-1A (upper gel) and of $\beta$-actin (lower gel) protein expression at different times of exposure of $\mathrm{H} 1355$ cells to $2500 \mathrm{IU} / \mathrm{ml}$ IFN $\alpha$ performed with Western blotting as described in Material and Methods. (b) Representation of the densitometric intensity of eEF-1A band. The intensities of the bands were expressed as arbitrary units. Bars, S.D.s. (c) EF-1A mRNA (upper gel) or GAPDH (lower gel) expression analyzed on agarose gel by Northern blot analysis at different exposure times of $\mathrm{H} 1355$ cells to $2500 \mathrm{IU} / \mathrm{ml} \mathrm{IFN} \alpha$. (d) Representation of the densitometric intensity band ratio of eEF-1A and GAPDH that was used as internal control. The intensities of the bands were expressed in arbitrary units. Bars, S.D.s. (e) Immunoblotting analysis of eEF-1A isoform 1 (upper gel) and 2 (middle gel) protein expression at different times of exposure of $\mathrm{H} 1355$ cells to $2500 \mathrm{IU} / \mathrm{ml} \mathrm{IFN} \alpha$ performed with Western blotting as described in Material and Methods. Lower gel, $\beta$-actin was used as loading control. (f) Representation of the densitometric intensity of eEF-1A bands. The intensities of the bands were expressed as arbitrary units. Bars, S.D.s. ${ }^{*}$ These differences are statistically significant $(P<0.005)$. All the experiments were performed at least three times and they gave always similar results 
(Figure 1e and f). On the other hand, eEF-1A2 increased about twofold after $10 \mathrm{~min}$ and 2.3-fold after $30 \mathrm{~min}$ of treatment with IFN $\alpha$ (Figure 1e and $\mathrm{f}$ ). Because the increased expression of eEF-1A appeared to be independent of changes in mRNA expression, the role of IFN $\alpha$ in both the ubiquitination and proteasome-dependent degradation of eEF-1A was also investigated. H1355 cells were exposed or not to $2500 \mathrm{IU} / \mathrm{ml}$ of IFN $\alpha$ for 5 and $60 \mathrm{~min}$, in the absence or presence of the proteasome inhibitor lactacystin. At the selected times, eEF-1A was immunoprecipitated and blotted with an anti-ubiquitin antibody to evaluate ubiquitination. IFN $\alpha$ alone caused a significant reduction of ubiquitination detectable after $5 \mathrm{~min}$ of treatment, whereas IFN $\alpha$ in the presence of lactacystin induced an accumulation of the ubiquitinated eEF-1A (Figure 2a). However, the treatment of $\mathrm{H} 1355$ with lactacystin induced an increase of eEF-1A expression that was enhanced by the concomitant treatment with IFN $\alpha$ (Figure $2 \mathrm{~b}$ and $\mathrm{c}$ ). The accumulation of the elongation factor in the presence of lactacystin was because of the inhibition of its degradation by proteasome, as confirmed by the increase in the ubiquitinated isoform of the translation factor.

\section{eEF-1A siRNA potentiates the apoptosis induced by} IFN $\alpha$. To investigate the possible role of eEF-1A in apoptosis induced by IFN $\alpha$ in $\mathrm{H} 1355$ cells, the expression level of eEF$1 \mathrm{~A}$ was reduced by RNA interference. siRNA1 and siRNA2 were lipotransfected together or separately, and siRNA1 was the most efficient in lowering the expression level of eEF-1A. eEF-1A expression was almost reduced $80 \%$ at $72 \mathrm{~h}$ after transfection, whereas in cells transfected with a scramble RNA, eEF-1A expression was unaffected (Figure 3a,c and e). $\beta$-Actin was again used as loading control (Figure $3 b, d$ and e). Apoptosis was evaluated by analyzing annexin $\mathrm{V}$ expression on cell surface after treatment with IFN $\alpha$ for $48 \mathrm{~h}$. The treatment with IFN $\alpha$ was performed $72 \mathrm{~h}$ after transfection with scramble RNA or siRNA1. Apoptosis was recorded in $7 \%$ of non-transfected cells and in $35 \%$ of nontransfected cells treated with IFN $\alpha$ for $48 \mathrm{~h}$ (Figure $3 \mathrm{f}$ and $\mathrm{g}$, respectively). Transfection with siRNA1 for $72 \mathrm{~h}$ caused about $24 \%$ of apoptotic cells (Figure 3h), whereas the fraction of cells undergoing apoptosis in siRNA1-transfected cells treated with IFN $\alpha$ was about $75 \%$ (Figure $3 i$ ). No effect was observed in both untreated cells (Figure 3j) and IFN $\alpha$ treated cells (Figure $3 \mathrm{k}$ ) transfected with scramble RNA. These data confirmed the role of eEF-1A in the regulation of apoptosis in our experimental model, as the downmodulation of its levels by siRNA transfection alone was able to induce significant apoptosis. Moreover, eEF-1A downregulation potentiated the apoptosis induced by IFN $\alpha$, suggesting a protecting effect of a factor from IFN $\alpha$-induced apoptosis.

Post-translational modifications of eEF-1A induced by IFN $\alpha$. To assess if IFN $\alpha$ treatment of $\mathrm{H} 1355$ cells could affect post-translational modifications of the elongation factor, the expression profile of eEF-1A was analyzed by 2D gel Western blot. In comparison to untreated cells (Figure 4a), H1355 cells treated with IFN $\alpha$ showed an extra spot migrating towards a more acidic $\mathrm{pH}$ (Figure $4 \mathrm{~b}$ ) suggesting that in these cells, eEF-1A undergoes phosphorylation. Therefore, eEF-1A was analyzed for the presence of serine, threonine or tyrosine phosphorylated residues. Treatment of $\mathrm{H} 1355$ cells with IFN $\alpha$ led to increased eEF$1 \mathrm{~A}$ phosphorylation on both threonine and serine sites
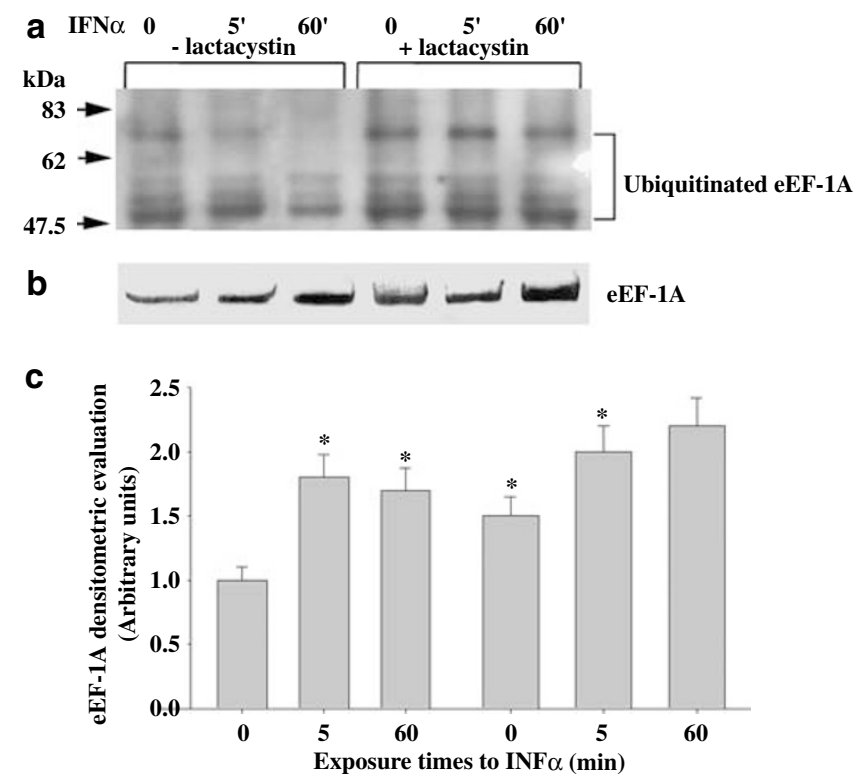

Figure 2 Effects of IFN $\alpha$ on the ubiquitination and proteasome-dependent degradation of eEF-1A in $\mathrm{H} 1355$ cells. $\mathrm{H} 1355$ cells were treated with $10 \mu \mathrm{M}$ lactacystin $1 \mathrm{~h}$ before the addition of $2500 \mathrm{IU} / \mathrm{ml}$ IFN $\alpha$ for the indicated times. (a) Ubiquitination of eEF-1A was determined by immunoprecipitating eEF-1A with anti-eEF-1A mAb and subsequent probing with anti-ubiquitin polyclonal antibody. (b) Under the same experimental conditions, the eEF-1A expression was also evaluated through Western blotting using a specific anti-eEF-1A mAb as described in Materials and Methods. (c) Band intensities associated to eEF-1A. The intensities of the bands are expressed in arbitrary units. Bars, S.D.s. ${ }^{*}$ These differences are statistically significant $(P<0.005)$. All the experiments were performed at least three times and they gave always similar results 
a
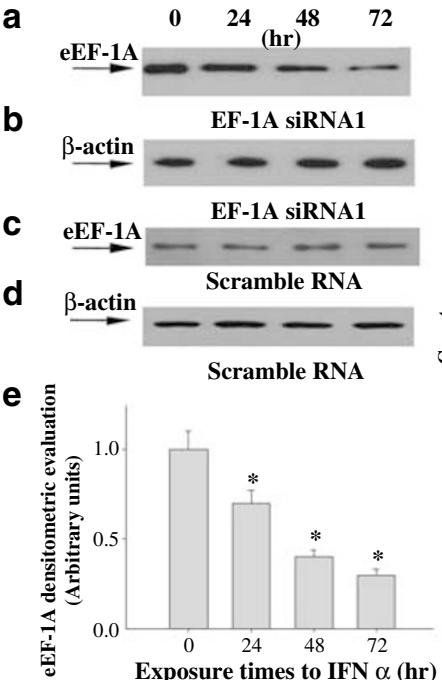
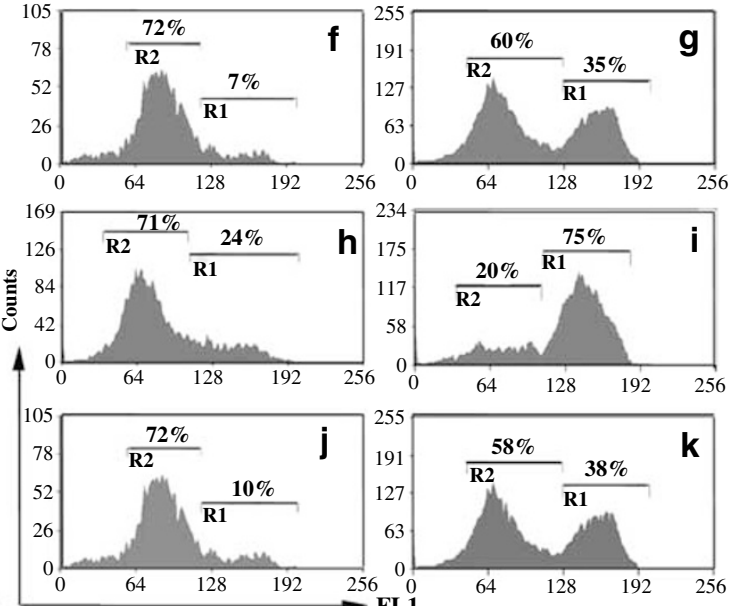

Figure 3 eEF-1A expression is involved in the regulation of apoptosis induced by IFN $\alpha$ in $\mathrm{H} 1355$ cells. (a and $\mathbf{b})$ Cells were lipotransfected with siRNA1, as described in Materials and Methods, and after different times of transfection, the expression of both eEF-1A (a) and $\beta$-actin (b) were evaluated by Western blotting. The transfection of scramble RNA had no effect on expression of both eEF-1A protein (c) and $\beta$-actin (d) expression. (e) Densitometric values of the bands associated to eEF-1A. The intensities of bands were expressed in arbitrary units. Bars, S.D.s. ${ }^{*}$ These differences are statistically significant $(P<0.005)$. (f-k) Cells were lipotransfected or not with $100 \mathrm{nM}$ siRNA1 or scramble RNA, and $72 \mathrm{~h}$ after the transfection, they were treated or not with $2500 \mathrm{IU} / \mathrm{ml} \mathrm{IFN} \alpha$ for $48 \mathrm{~h}$. The cells were then processed for the evaluation of surface expression of annexin V with FACS analysis as described in Materials and Methods. (f) Untreated parental cells; (g) $2500 \mathrm{IU} / \mathrm{ml} 48 \mathrm{~h} \mathrm{IFN} \alpha$-treated parental cells; (h) Untreated siRNA1 transfected cells; (i) $2500 \mathrm{IU} / \mathrm{ml} 48 \mathrm{~h}$ IFN $\alpha$-treated siRNA1 transfected cells; (j) untreated scramble RNA transfected cells; (k) $2500 \mathrm{IU} / \mathrm{ml} 48 \mathrm{~h}$ IFN $\alpha$-treated scramble RNA transfected cells. R1: non-apoptotic cells; R2: apoptotic cells. All the experiments were performed at least three times and gave always similar results

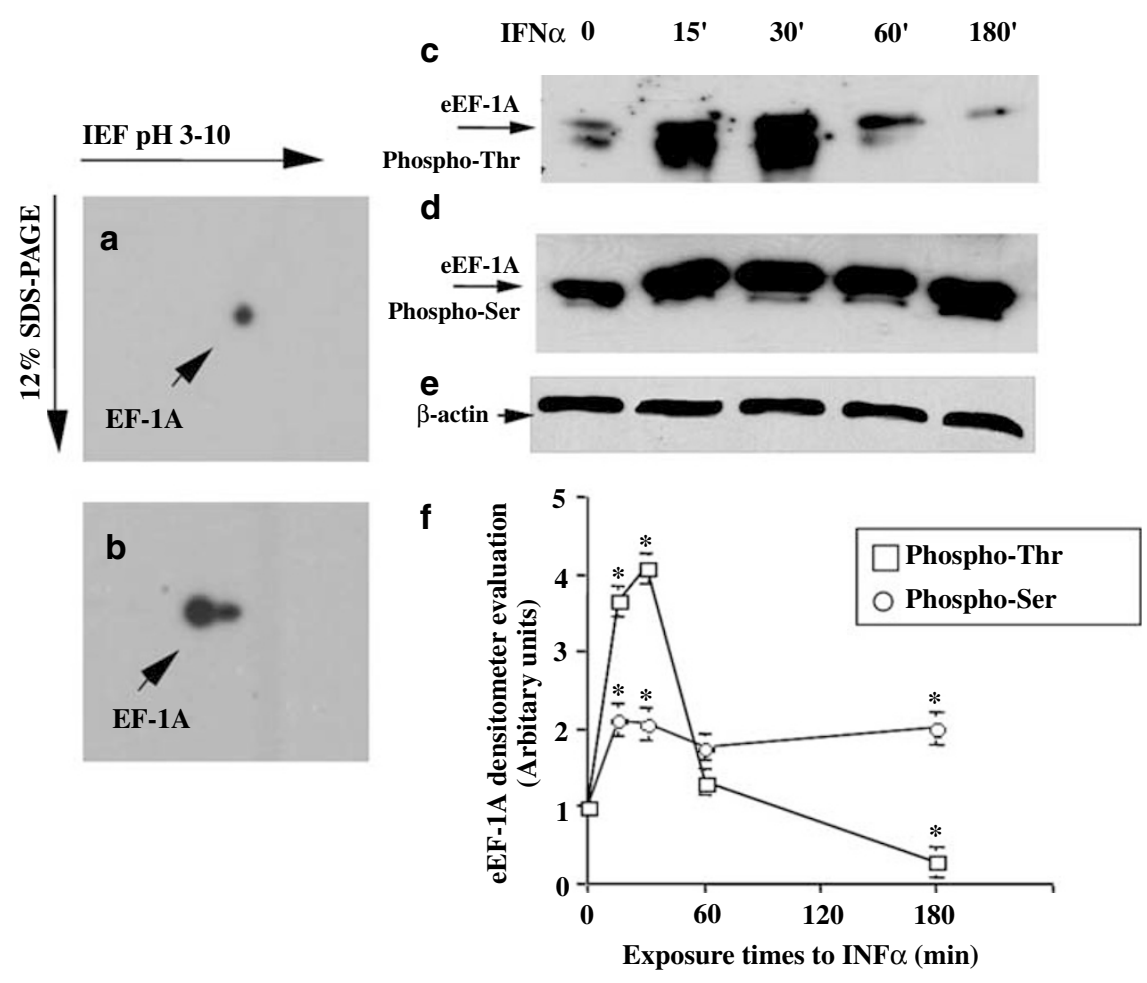

Figure 4 Post-translational modifications of eEF-1A are induced by IFN $\alpha$ in $\mathrm{H} 1355$ cells. Two-dimensional gel electrophoresis of proteins extracted from H1355 cells (a) unexposed or (b) exposed to $2500 \mathrm{IU} / \mathrm{ml}$ IFN $\alpha$ for $15 \mathrm{~min}$ and subsequently blotted for the determination of eEF-1A. For the technical details see Materials and Methods. (c and d) eEF-1A was immunoprecipitated and analyzed by Western blotting with either (c) an anti-phospho-threonine polyclonal antibody or (d) an anti-phosphoserine mAb as described in Materials and Methods. (e) Densitometric values of the bands associated to phosphothreonine $(\square)$ or phosphoserine $(O)$ in eEF-1A. The intensities of the bands were expressed as arbitrary units. Bars, S.D.s. ${ }^{*}$ These differences are statistically significant $(P<0.005)$. All the experiments were performed at least three times and gave always similar results 
(Figure 4c and d) with the maximal phosphorylation degree of about fourfold and twofold increase for serine and threonine, respectively (Figure 4f). No phosphorylation was observed with the anti-phosphotyrosine antibody (data not shown). Moreover, threonine phosphorylation was maximally increased at $30 \mathrm{~min}$ and again reached the basal levels after $60 \mathrm{~min}$, whereas serine phosphorylation augmented after 15 min of treatment with IFN $\alpha$ and remained high up to $180 \mathrm{~min}$ of exposure time (Figure 4f). These data demonstrated that IFN $\alpha$ phosphorylates eEF-1A on both serine and threonine residues.

eEF-1A co-immunoprecipitates with C-Raf in H1355 cells. We have previously reported that IFN $\alpha$ activates an anti-apoptotic pathway mediated by an EGF-ras $\rightarrow$ C-Raf $\rightarrow$ Mek signal transduction pathway. ${ }^{19}$ Therefore, it was analyzed if this pathway was responsible for the phosphorylation of eEF-1A. H1355 cells, exposed or not to IFN $\alpha$, were immunoprecipitated with anti-eEF-1A or antiC-Raf antibody and blotted with anti-C-Raf or anti-eEF-1A antibody, respectively. In samples immunoprecipitated with anti-eEF-1A, a band of about $80 \mathrm{kDa}$ corresponding to C-Raf was detected (Figure 5a) and, in samples immunoprecipitated with anti-C-Raf, a band of about $50 \mathrm{kDa}$ was detected, corresponding to the molecular weight of eEF-1A (Figure 5b). Evaluation of the ratio between

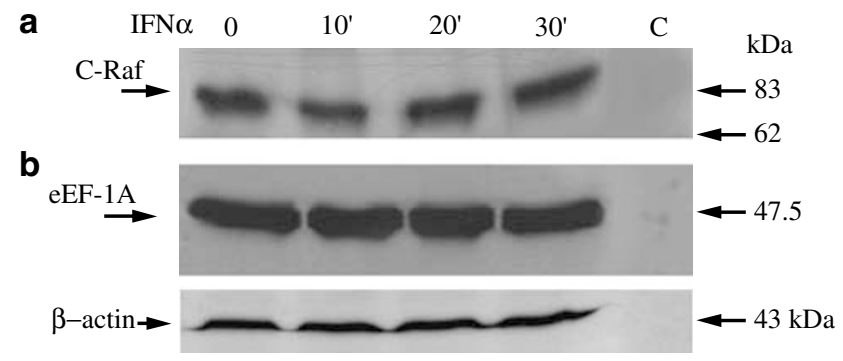

c

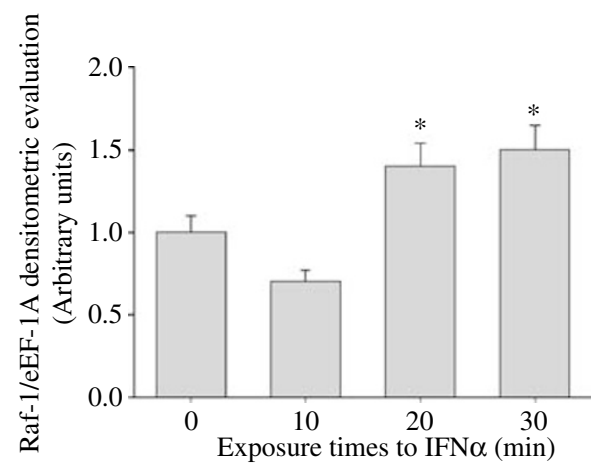

Figure 5 Interaction between eEF-1A and C-Raf in H1355 cells. H1355 cells were treated at the indicated times with $2500 \mathrm{IU} / \mathrm{ml} \mathrm{IFN} \alpha$ and, thereafter, proteins were extracted. (a) eEF-1A was immunoprecipitated and analyzed by Western blot with an anti-C-Raf polyclonal antibody. (b) C-Raf was immunoprecipitated and analyzed by Western blot with an anti-eEF-1A mAb. In lane $C$, the antibodies were run without cell lysates as negative controls. (c) Representation of the densitometric intensity band ratio of eEF-1A and C-Raf. The intensities of the bands were expressed as arbitrary units. Bars, S.D.s. ${ }^{*}$ These differences are statistically significant $(P<0.005)$. All the experiments were performed at least three times and gave always similar results
C-Raf and eEF-1A band intensity demonstrated about $50 \%$ increase of C-Raf/eEF1A interaction after 20-30 min of treatment with IFN $\alpha$ (Figure $5 \mathrm{c}$ ). These results demonstrated that the two proteins interacted with each other in basal conditions and that IFN $\alpha$ enhanced this interaction.

C-Raf phosphorylates eEF-1A on serine and threonine residues. To confirm that $e E F-1 A$ is a substrate of the serine-threonine kinase $\mathrm{C}$-Raf, $\mathrm{H} 1355$ cells were treated with the C-Raf kinase inhibitor BAY 43-9006, and its effects on both phosphorylation and expression of eEF-1A were evaluated. $\mathrm{H} 1355$ cells were preliminarily exposed to $5 \mu \mathrm{M}$ BAY 43-9006 for different times and the activity of the downstream target Erk was evaluated. It was found that $120 \mathrm{~min}$ of exposure to BAY 43-9006 induced almost complete disappearance of Erk-1/2 phosphorylation (not shown). Therefore, in all subsequent experiments, H1355 cells were pre-treated with BAY 43-9006 for $120 \mathrm{~min}$ and then exposed to IFN $\alpha$ for different times. After treatment with BAY 43-9006, both phosphothreonine and phosphoserine levels of eEF-1A were reduced (Figure $6 a$ and b). BAY 43-9006 completely antagonized the increase of eEF-1A expression induced by IFN $\alpha$, hence caused a reduction of eEF-1A protein levels either alone or in combination with IFN $\alpha$ (Figure 6c). On the other hand, IFN $\alpha$ increased eEF-1A expression with a peak at $30 \mathrm{~min}$ as reported above (Figure 6c). Moreover, eEF-1A was immunoprecipitated and blotted with anti-ubiquitin antibody to evaluate the ubiquitination of eEF-1A. It was found that IFN $\alpha$ alone decreased the ubiquitination levels of the factor after 30 and $60 \mathrm{~min}$ of treatment, whereas BAY 43-9006 completely antagonized this effect even inducing a clear increase of ubiquitination after 30 and $60 \mathrm{~min}$ of incubation of the cells with IFN $\alpha$ (Figure $6 \mathrm{~d}$ ). The treatment of $\mathrm{H} 1355$ cells with BAY 43-9006 induced a strong reduction of Erk phosphorylation without modulating Erk expression (Figure $6 \mathrm{e}$ and f). eEF-1A phosphorylation was also evaluated by an in vitro assay. In the presence of ${ }^{32} \mathrm{P}-\gamma$-ATP, recombinant $\mathrm{C}$-Raf was able to phosphorylate eEF-1A immunoprecipitated with anti-eEF-1A antibody (Figure 6g).

To exclude the involvement of other downstream kinases in the same pathway in the phosphorylation of eEF-1A, H1355 cells were exposed to the MEK-1 inhibitor U0126. Cells were pre-treated with $10 \mu \mathrm{M}$ U0126 for $1 \mathrm{~h}$ and then exposed to IFN $\alpha$ at different times. U0126 did not induce any change in phosphothreonine and phosphoserine levels of eEF-1A (Figure $6 \mathrm{~h}$ and i). Moreover, U0126 decreased Erk-1/2 phosphorylation without altering Erk expression (Figure 6j and $\mathrm{k}$ ). In addition, U0126 was not able to modify eEF-1A expression either alone or in combination with IFN $\alpha$ (Figure 6I). On the basis of these results, we have investigated whether BAY 43-9006 could antagonize the increase of eEF$1 \mathrm{~A}$ induced by IFN $\alpha$ and at the same time, enhance the apoptosis caused by the cytokine in H1355 cells. After treatment with BAY 43-9006, H1355 cells were exposed or not to IFN $\alpha$ for $30 \mathrm{~min}$ or $12 \mathrm{~h}$ to evaluate eEF-1A expression or apoptosis (Figure $6 \mathrm{~m}$ and $\mathrm{n}$ ) at FACS analysis. About $29 \%$ of untreated cells overexpressed eEF-1A, whereas about $64.8 \%$ of cell population exposed to IFN $\alpha$ for $30 \mathrm{~min}$ showed 

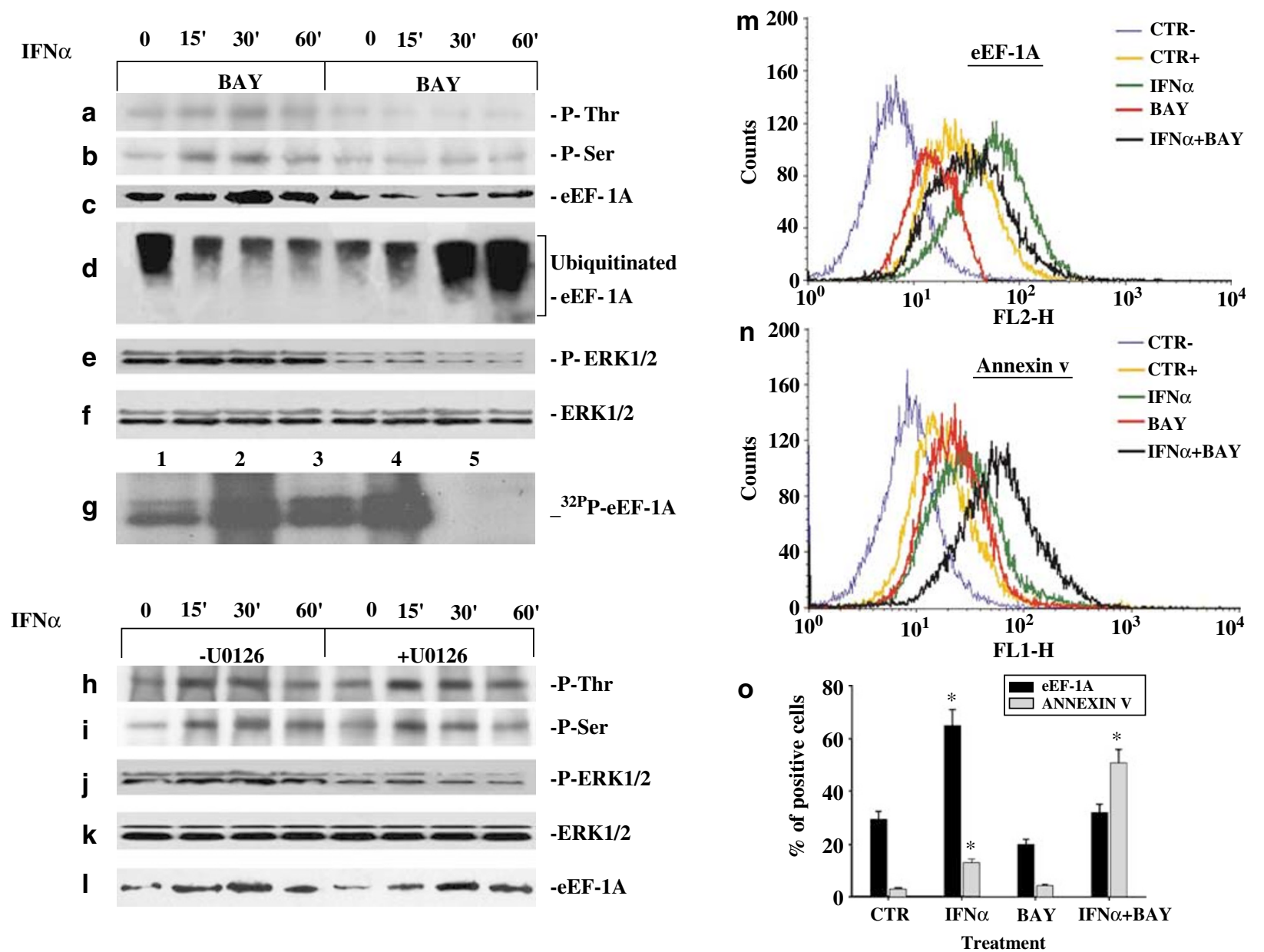

Figure 6 Role of C-Raf in the regulation of eEF-1A phosphorylation and expression, and on the apoptosis induced by IFN $\alpha$. (a-f) $\mathrm{H} 1355$ cells were treated with $5 \mu \mathrm{M}$ BAY 43-9006 for $120 \mathrm{~min}$ and, after BAY 43-9006 removal, they were exposed or not to $2500 \mathrm{IU} / \mathrm{ml}$ IFN $\alpha$ and at the indicated times proteins were extracted as described in Materials and Methods and analyzed by Western blot. eEF-1A was immunoprecipitated and analyzed with (a) anti-phosphothreonine and (b) anti-phosphoserine for the detection of eEF-1A phosphorylation levels. (c) eEF-1A expression was evaluated with a specific anti-eEF-1A antibody as described in Materials and Methods. (d) eEF-1A was immunoprecipitated and analyzed with anti-ubiquitin for the detection of eEF-1A ubiquitination. Evaluation of the expression by Western blot, in the same experimental conditions, of (e) pErk 1/2 and (f) Erk 1/2. (g) In vitro phosphorylation of eEF-1A. Lanes 1 and 2: $200 \mu \mathrm{g}$ of H1355 cell extract were immunoprecipitated with $2 \mu \mathrm{g}$ of eEF-1A antibody and incubated with 40 or 80 units of C-Raf. Lanes 3 and 4: $400 \mu \mathrm{g}$ of H1355 cell extract were immunoprecipitated with $4 \mu \mathrm{g}$ of eEF-1A antibody and incubated with 40 or 80 units of C-Raf. Lane 5: Assay performed in the absence of cell extract. (H-L) H1355 cells were treated with $10 \mu \mathrm{M} \mathrm{U0126}$ for $1 \mathrm{~h}$, after U0126 removal, the cells were exposed or not to $2500 \mathrm{IU} / \mathrm{ml} \mathrm{IFN} \alpha$ and, at the indicated times, proteins were extracted, and eEF-1A was immunoprecipitated and analyzed with (h) anti-phosphothreonine, (i) anti-phosphoserine for the detection of eEF-1A phosphorylation levels. Evaluation of the expression by Western blot, in the same experimental conditions, of (j) pErk 1/2, (k) Erk $1 / 2$ and (I) eEF-1A. All the experiments were performed at least three times and gave always similar results. (m and $\mathbf{n}) \mathrm{H} 1355$ cells were treated with $5 \mu \mathrm{M}$ BAY $43-9006$ for $120 \mathrm{~min}$ and, after BAY 43-9006 removal, they were exposed or not to $2500 \mathrm{UI} / \mathrm{ml} \mathrm{IFN} \alpha$ for either $30 \mathrm{~min}(\mathrm{~m})$ or $12 \mathrm{~h}(\mathrm{n})$. The cells were then processed for the evaluation of the intracytoplasmic expression of eEF-1A (m) and for surface expression of annexin V $(\mathbf{n})$ with FACS analysis as described in Materials and Methods. (m) CTR-: untreated cells exposed to an irrelevant antibody; CTR + : untreated cells; IFN $\alpha$ : cells treated with $2500 \mathrm{IU} / \mathrm{ml}$ IFN $\alpha$ for $30 \mathrm{~min}$; BAY: cells exposed to $5 \mu \mathrm{M}$ BAY $43-9006$ for $120 \mathrm{~min}$; IFN $\alpha+$ BAY: cells exposed to $5 \mu \mathrm{M}$ BAY 43-9006 for $120 \mathrm{~min}$ and, after BAY 43-9006 removal, exposed to $2500 \mathrm{IU} / \mathrm{ml}$ IFN $\alpha$ for 30 min. (n) CTR-: untreated cells not exposed to FITC-conjugated annexin V; CTR + : untreated cells; IFN $\alpha$ : cells treated with $2500 \mathrm{IU} / \mathrm{ml}$ IFN $\alpha$ for $12 \mathrm{~h}$; BAY: cells exposed to $5 \mu \mathrm{M} \mathrm{BAY} 43-9006$ for $120 \mathrm{~min}$; IFN $\alpha+$ BAY: cells exposed to $5 \mu \mathrm{M}$ BAY 43-9006 for $120 \mathrm{~min}$ and, after BAY 43-9006 removal, exposed to $2500 \mathrm{IU} / \mathrm{ml}$ IFN $\alpha$ for $12 \mathrm{~h}$. (o) Representation of the percentage of cells either overexpressing eEF1A or apoptotic in the different treatment settings. Bars, S.D.s. ${ }^{*}$ These differences are statistically significant $(P<0.005)$. CTR, untreated cells; IFN $\alpha$, cells treated for $30 \mathrm{~min}$ or $12 \mathrm{~h}$ with $2500 \mathrm{IU} / \mathrm{ml} \mathrm{IFN} \alpha$; BAY, cells treated with BAY 43-9006 for $120 \mathrm{~min}$; IFN $\alpha+$ BAY, cells treated with BAY 43-9006 for $120 \mathrm{~min}$ and, after BAY 43-9006 removal, with $2500 \mathrm{IU} / \mathrm{ml} \mathrm{IFN} \alpha$ for $30 \mathrm{~min}$ or $12 \mathrm{~h}$

high levels of eEF-1A (Figure $6 \mathrm{~m}$ and o). The treatment of H1355 cells with BAY 43-9006 caused a slight decrease of cells positive for eEF-1A (about 20\%), but the sequential treatment of the cells with BAY 43-9006 and IFN $\alpha$ for $30 \mathrm{~min}$ completely antagonized the increase of eEF-1A expression induced by IFN $\alpha$ (Figure $6 \mathrm{~m}$ and o). In fact, about $32.2 \%$ of cells were positive for eEF-1A expression in these experi- mental conditions (Figure 6o). Moreover, we have found that only $3 \%$ of the untreated cells were apoptotic whereas $12 \mathrm{~h}$ IFN $\alpha$ induced apoptosis in about $13 \%$ of cell population (Figure $6 \mathrm{n}$ and $\mathrm{o}$ ). The treatment of $\mathrm{H} 1355$ cells with BAY 43-9006 induced about $4.3 \%$ apoptosis whereas the exposure to $12 \mathrm{~h}$ IFN $\alpha$ of $\mathrm{H} 1355$ cells pre-treated with BAY 439006 caused apoptosis in about $50.8 \%$ of cell population (Figure 
$6 n$ and o). These data demonstrate that BAY 43-9006 is able to antagonize the increased phosphorylation and expression of eEF-1A induced by IFN $\alpha$ and that these effects are paralleled by a decrease in the ubiquitination of the translation factor and an increase in the apoptosis induced by the cytokine.

To demonstrate that IFN $\alpha$ modulates eEF-1A ubiquitination, we have transfected $\mathrm{H} 1355$ cells with the K48R ubiquitin mutant (K48R) and evaluated the expression of the translation factor before and after treatment with IFN $\alpha$. The transfection with wild type (WT) ubiquitin induced an increase in the pattern of ubiquitination of intracellular proteins, whereas the transfection with $\mathrm{K} 48 \mathrm{R}$ caused an increase in the low molecular mass isoforms and those at high molecular mass decreased, suggesting an inhibition of poly-ubiquitination (Figure 7a). These experiments were performed at $24 \mathrm{~h}$ from the transfection when the maximal increase of green fluorescent cells induced by GFP was detected (Figure 7d and $e$ ). IFN $\alpha$ again induced an increase of eEF-1A expression in cells transfected with an irrelevant plasmid at 15 and $30 \mathrm{~min}$ from the beginning of the treatment (Figure $7 b$ and $c$ ). The transfection with K48R caused per se an increase of the eEF$1 \mathrm{~A}$ expression, which on the other hand, was slightly decreased in WT-transfected cells (Figure $7 \mathrm{~b}$ and $\mathrm{c}$ ). IFN $\alpha$ added to K48R-transfected cells failed to increase eEF-1A expression that was already increased in untreated cells, whereas IFN $\alpha$ again enhanced eEF-1A expression in WTtransfected cells (Figure $7 \mathrm{~b}$ and $\mathrm{c}$ ). These data suggest that IFN $\alpha$ is unable to affect eEF-1A protein half-life in cells in which ubiquitin mutated sites responsible for poly-ubiquitination is overexpressed.

The functional interaction between eEF-1A and C-Raf was also analyzed by confocal microscopy (Figure 8). In fact, in untreated cells, the two proteins partially colocalized in the cells, and the colocalization was increased by the treatment with IFN $\alpha$ for 30 min (Figure $8 a-c$ and $8 d-f$ ). Subsequently, $\mathrm{H} 1355$ cells were treated with BAY 43-9006 that reduced colocalization of C-Raf with eEF-1A in untreated cells and antagonized the colocalization of the two proteins induced by IFN $\alpha$ (Figure $8 \mathrm{~g}-\mathrm{i}$ and $\mathrm{j}-\mathrm{I})$.

Prediction of putative phosphorylated serine and threonine residues in eEF-1A. To predict the eEF-1A putative phosphorylation sites, a combined strategy involving molecular modelling and molecular dynamic simulation was used. In Figure $8 \mathrm{~m}$ and $\mathrm{n}$, the root mean square deviation (RMSD) is plotted as a function of time for the $2.0 \mathrm{~ns}$ simulation. After an initial rise of the RMSD to $0.2 \mathrm{~nm}$, the RMSD gradually rose to $0.4 \mathrm{~nm}$ and after $0.5 \mathrm{~ns}$ remained fluctuating around this value during the simulation. Figure $8 \mathrm{~m}$ shows the final structure of eEF-1A after dynamic simulation. By searching in PhosphoBase for Ser/Thr residues that are putative targets of phosphorylation, kinase specific motifs were recognized in the human eEF-1A protein and a score was attributed to each Ser and Thr (Supplementary Table 1). The recognized phosphorylation motifs were further selected on the basis of the value of two additional structural properties after $2.0 \mathrm{~ns}$ dynamic simulation, that is, the secondary structure and solvent accessibility. In fact, statistical analysis of protein kinase specificity determinants showed that most of the phosphorylation sites were located

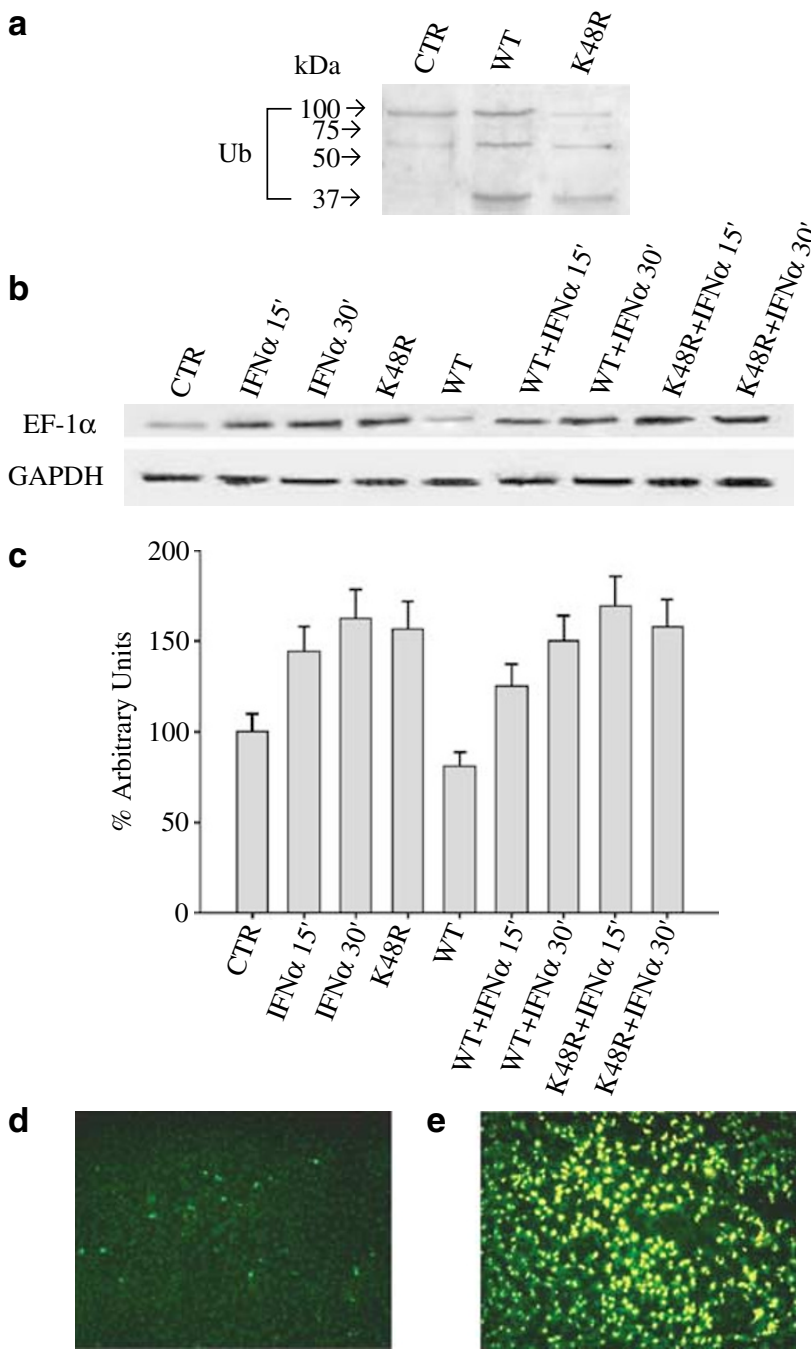

Figure 7 Role of ubiquitination in the regulation of eEF-1A expression induced by IFN $\alpha$. (a and $\mathbf{b}$ ) H1355 cells were transfected with an empty vector or with WT ubiquitin or with K48R ubiquitin as described in Materials and Methods. After $24 \mathrm{~h}$ of transfection, the cells were treated or not with $2500 \mathrm{IU} / \mathrm{ml}$ IFN $\alpha$ and, at the indicated times, proteins were extracted and analyzed by Western blot. (a) Proteins were blotted and film probed with an anti-ubiquitin antibody as previously described. CTR, control cells transfected with an empty vector; WT, WT ubiquitin-transfected cells; K48R, K48R ubiquitin-transfected cells. (b) Proteins were blotted and film probed with anti-eEF-1A antibody as described previously. CTR, control cells transfected with an empty vector; IFN $\alpha 15^{\prime}$ : parental cells treated with $2500 \mathrm{IU} / \mathrm{ml} \mathrm{IFN} \alpha$ for $15 \mathrm{~min}$; IFN $\alpha 30^{\prime}$ : parental cells treated with $2500 \mathrm{IU} / \mathrm{ml} \mathrm{IFN} \alpha$ for $30 \mathrm{~min}$; WT, untreated WT ubiquitin-transfected cells; K48R, untreated K48R ubiquitintransfected cells; K48R + IFN $\alpha 15^{\prime}, K 48 R$ ubiquitin-transfected cells treated with $2500 \mathrm{IU} / \mathrm{ml} \mathrm{IFN} \alpha$ for $15 \mathrm{~min}$; K48R + IFN $\alpha 30^{\prime}, \mathrm{K} 48 \mathrm{R}$ ubiquitin-transfected cells treated with $2500 \mathrm{IU} / \mathrm{ml} \mathrm{IFN} \alpha$ for $30 \mathrm{~min}$; WT + IFN $\alpha 15^{\prime}$, WT ubiquitin-transfected cells treated with $2500 \mathrm{IU} / \mathrm{ml} \mathrm{IFN} \alpha$ for $15 \mathrm{~min}$; WT $+\mathrm{IFN} \alpha 30^{\prime}$, WT ubiquitintransfected cells treated with $2500 \mathrm{IU} / \mathrm{ml}$ IFN $\alpha$ for $30 \mathrm{~min}$. (c) Representation of the densitometric intensity band of eEF-1A. The intensities of the bands were expressed as arbitrary units. Bars, S.D.s. All the experiments were performed at least three times and gave always similar results. ${ }^{*}$ These differences are statistically significant $(P<0.005)$. (d and e) Cells were transfected with an empty vector $(\mathbf{d})$ or with K48R ubiquitin plasmid (e) as described previously in Materials and Methods. After $24 \mathrm{~h}$ of transfection, cells were visualized and photographed at a fluorescence microscopy $(\times 10)$ 

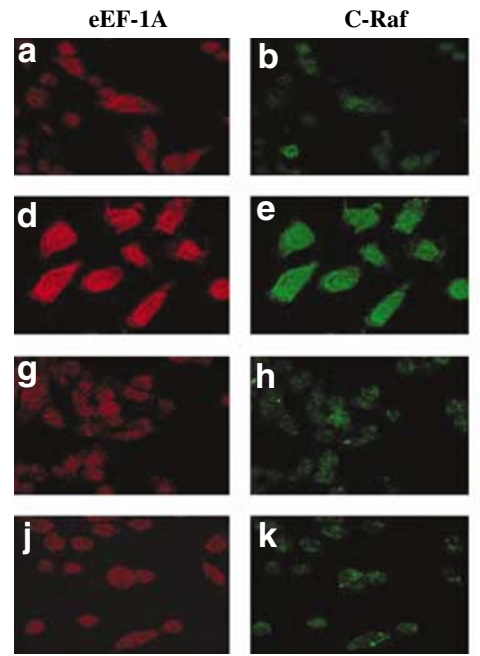
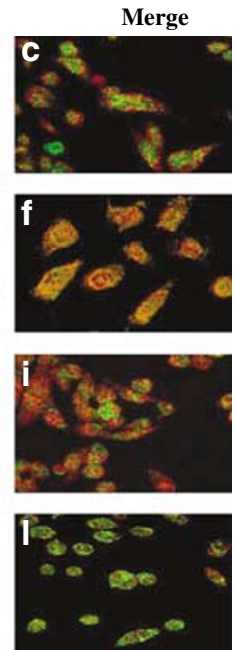
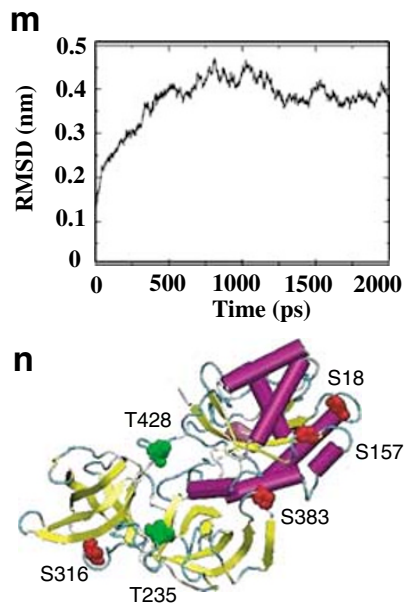

Figure 8 Colocalization of eEF-1A and C-Raf in H1355 cells and 3D model of human eEF-1A after dynamic simulation. H1355 cells were pretreated with $5 \mu$ M BAY $43-$ 9006 for $120 \mathrm{~min}$, exposed to $2500 \mathrm{IU} / \mathrm{ml} \mathrm{IFN} \alpha$ for $20 \mathrm{~min}$ and processed for the visualization of eEF-1A and C-Raf at confocal microscopy as described in Materials and Methods. eEF-1A: eEF-1A immuno-visualization; C-Raf: C-Raf immuno-visualization; Merge: fluorescence overlapping. (a-c) Untreated cells; (d-f) 30 min 2500 IU/ml IFN $\alpha$; (g-i) 120 min $5 \mu \mathrm{M}$ BAY 43-9006, (j-I) 120 min $5 \mu \mathrm{M}$ BAY 43-9006 followed by $30 \mathrm{~min} 2500 \mathrm{IU} / \mathrm{ml}$ IFN $\alpha$. (m) RMSD of eEF-1A structure. The RMSD of eEF-1A atoms is plotted as function of time for $2.0 \mathrm{~ns}$ molecular dynamic simulation. (n) The position of Ser and Thr residues with high phosphorylation probability is shown in red and green, respectively

on the surface of the protein where they are solvent accessible and are part of unstructured segments ${ }^{23}$ (Supplementary Table 1). Figure 8 n shows the localization of most probable phosphorylation sites for Ser and Thr residues (Ser18, 157, 316, 383 and Thr242, 432, respectively) within the $3 \mathrm{D}$ model of human eEF-1A.

\section{Discussion}

In this paper we have investigated eEF-1A role in the apoptotic processes triggered by IFN $\alpha$ in $\mathrm{H} 1355$ cell line analyzing the functional and molecular interactions between eEF-1A and C-Raf. In our experimental model, IFN $\alpha$ induced an early upregulation of eEF-1A without increase in the levels of its transcripts. This finding suggested that the upregulation of the intracellular content of eEF-1A was post-transcriptionally modulated. Moreover, we have found that the cytokine increased both eEF-1A1 and eEF-1A2 but with a difference in degree and kinetics. In fact, eEF-1A2 was the most increased isoform and also showed a timing similar to the one recorded for total eEF-1A. These data suggested that eEF-1A2 increase was largely responsible for the upregulation of total eEF-1A. It has been reported that eEF-1A possesses a chaperone-like activity that prevents the aggregation of nascent polypeptide chains ${ }^{24}$ and interacts with ubiquitinproteasome complex. ${ }^{10}$ Moreover, we have described previously that IFN $\alpha$ modulates the ubiquitination of proteins, such as tissue transglutaminase, involved in the regulation of apoptosis in $\mathrm{H} 1355$ cells. ${ }^{25}$ Therefore, it was speculated that the increase in eEF-1A protein expression could be owing to a regulatory mechanism in which the elongation factor levels are modulated through an ubiquitin-dependent pathway. In fact, IFN $\alpha$ decreased ubiquitinated eEF-1A and treatment of $\mathrm{H} 1355$ cells with the proteasome inhibitor lactacystin led to an accumulation of the ubiquitinated form of eEF-1A. This is, to our knowledge, the first report showing that IFN $\alpha$ increases eEF-1A expression through decrease of its ubiquitination and its possible rescue from proteasome-dependent degradation. To investigate the potential survival role of the increase in eEF-1A protein levels, the apoptotic response of the cells to IFN $\alpha$ was evaluated in cells in which eEF-1A was downmodulated by siRNA. In cells expressing low levels of eEF-1A, the apoptotic cell death induced by IFN $\alpha$ was potentiated suggesting that eEF-1A regulates the apoptosis in $\mathrm{H} 1355$.

Moreover, it was evaluated if eEF-1A could be found in different modified states through 2D gel electrophoresis. We found an additional spot of eEF-1A in IFN $\alpha$-treated $\mathrm{H} 1355$ cells. The slight migration of the new protein toward an acidic $\mathrm{pH}$ could be caused by posttranslational phosphorylation. It was found that IFN $\alpha$ increased the phosphorylation of both serine and threonine residues in eEF-1A. Because in the same experimental model, IFN $\alpha$ induces an increase in the level and activity of epidermal growth factor receptor (EGF-R) and of the Ras $\rightarrow$ C-Raf $\rightarrow$ Mek $1 \rightarrow$ Erk-1/2 signalling pathway that has a prominent role in anti-apoptotic effects, ${ }^{19}$ it was evaluated if the phosphorylation of eEF-1A could be mediated by $\mathrm{C}$-Raf. It was found that eEF-1A indeed interacts with $\mathrm{C}$ Raf and these effects could be potentiated by IFN $\alpha$. Moreover, when the C-Raf kinase activity was blocked by Raf kinase inhibitor BAY 43-9006, a reduction in eEF-1A phosphoserine and phosphothreonine levels was found. IFN $\alpha$ was also able to decrease the ubiquitination of eEF-1A, and BAY 43-9006 completely blocked this effect and even induced a strong increase of the ubiquitination of the translation factor. These findings strongly support the hypothesis that the phosphorylation of eEF-1A by C-Raf is required to increase the intracellular half-life of the protein and to protect the latter from proteasome-dependent degradation. The antagonism of BAY 43-9006 on the eEF-1A overexpression induced by IFN $\alpha$ was also paralleled by a strong increase of apoptosis 
supporting the role of eEF-1A in the protection of cancer cells from the apoptosis induced by the cytokine. Therefore, these data suggest the existence of an anti-apoptotic network between translational factors, such as eEF-1A, and components of the ras-dependent signalling as C-Raf. The transfection of $\mathrm{H} 1355$ cells with K48R mutant ubiquitin induced per se an increase in the expression of eEF-1A that did not increase further by the treatment with IFN $\alpha$. On the other hand, the overexpression of WT ubiquitin induced a slight decrease of eEF-1A that was again modulated by IFN $\alpha$ addition. Moreover, IFN $\alpha$ is unable to increase the expression of the translational factor when compared with K48R ubiquitintransfected cells. These data support the hypothesis that eEF-1A is indeed poly-ubiquitinated and that the overexpression of an ubiquitin mutant lacking the site responsible for poly-ubiquitination is alone able to increase the expression of eEF-1A. On the other hand, the overexpression of WT ubiquitin increases the poly-ubiquitination and consequent degradation of eEF-1A slightly decreasing its expression. IFN $\alpha$ caused again an increase in the expression of eEF-1A when compared to both non-transfected and WT ubiquitintransfected cells. These data altogether suggest that eEF-1A expression is indeed modulated via an ubiquitin-dependent pathway. We also found that U0126, a Mek-1 inhibitor, was unable to affect the changes induced by IFN $\alpha$ in eEF-1A phosphorylation and expression and in the colocalization of eEF-1A/C-Raf in vivo, suggesting the specific involvement of $\mathrm{C}$-Raf in these changes. Finally, the in vitro kinase assay clearly showed that eEF-1A can be a substrate of C-Raf.

Moreover, we used the 3D structure of EF-1A GDP from Sulfolobus solfataricus as a template for the prediction of phosphorylation putative sites. ${ }^{26}$

To conclude, in the human epidermoid lung cancer cells, $\mathrm{H} 1355$, the upregulation of eEF-1A intracellular content mediated by IFN $\alpha$ is associated with an increase in the phosphorylation of serine and threonine residues of the protein. Our findings indicate that the effect is mediated by C-Raf, and appears to play a pro-survival function. On the basis of our previous findings, we propose that activation of $C$ Raf by IFN $\alpha$ is presumably indirect and induced by upregulation of EGF-R. Moreover, for the first time, a well-known client of HSP90, C-Raf, degraded via a proteasome-dependent pathway, ${ }^{27}$ has been demonstrated to protect eEF-1A from ubiquitin-mediated degradation. Therefore, eEF-1A is an antiapoptotic factor whose activity links the protein synthesis machinery to growth factor-elicited survival pathway and represents an important molecular target to improve strategies based on apoptosis induction.

\footnotetext{
Materials and Methods

Materials. RPMI 1640 medium and fetal bovine serum (FBS) were purchased from Cambrex. IFN $\alpha$ was a gift from Schering Plough (Nutley, NJ, USA). Bay 439006 was a gift from Bayer Pharmaceuticals Corporation, West Haven, CT, USA. Protein A-Agarose, anti-C-Raf C-12, anti-ubiquitin FL76, anti-actin I-19, antiphosphothreonine, anti-Erk, anti-pErk polyclonal antibodies, rabbit anti-mouse and goat anti-rabbit immunoglobulin conjugated to horseradish peroxidase were from Santa Cruz Biotechnology (Santa Cruz, CA, USA). Anti-phosphoserine PSR-45 monoclonal antibody $(\mathrm{mAb})$ and lactacystin were from Sigma (Milan, Italy). AntieEF-1A CB-KK1 mAb was purchased from Upstate (Charlottesville, VA, USA). Irrelevant mouse $\lg \mathrm{G} 1$ was purchased form DAKO (Bastrup, Denmark). Recombinant Raf-1 was purchased from GloboZymes (Carlsbad, CA, USA).
}

U0126 was from Promega (Madison, WI, USA). Other primary antibodies used were HT7 for eEF1A-1/EF-1 $\alpha$, CB5 for eEF1A-2/S1. ${ }^{28}$ The construction of both plasmids pDG268, the WT vector in which expression of a linear fusion of His6-tagged human ubiquitin and enhanced GFP is driven by the human UBC promoter, and pDG279, containing the K48R mutant version of ubiquitin, has been described elsewhere. ${ }^{29}$

Cell culture. The human lung epidermoid carcinoma H1355 cell line, obtained from American Type Tissue Collection (Rockville, MD, USA), was grown in RPMI 1640 medium supplemented with heat inactivated FBS, $100 \mathrm{U} / \mathrm{ml}$ penicillin, $100 \mu \mathrm{g} /$ $\mathrm{ml}$ streptomycin, $1 \%$ L-glutamine at $37^{\circ} \mathrm{C}$ in a $5 \% \mathrm{CO}_{2}$ atmosphere. For RNA hybridization, Western blot analysis and apoptosis evaluation, the cells were treated with $2500 \mathrm{IU} / \mathrm{ml} \mathrm{IFN} \alpha$.

Northern blot analysis. Cytoplasmic RNA was extracted from cells using Trizol reagent (Gibco BRL). RNA (2 $\mu \mathrm{g}$ ) was resolved on formaldehyde agarose gel, transferred to nylon membrane and hybridized to ${ }^{32} \mathrm{P}$-labeled EF-1A cDNA (clone pAN7) or ${ }^{32} \mathrm{P}$-labeled GAPDH CDNA ${ }^{30}$ probes as described by Maniatis et al..$^{31}$

Cytosolic extracts and Western blot analysis. H1355 cells were scraped, washed twice in cold phosphate-buffered saline (PBS) and resuspended in 20-40 $\mu$ l of lysis buffer $(50 \mathrm{mM}$ Tris- $\mathrm{HCl}$ pH 7.4, $1 \% \mathrm{NP} 40,0.25 \%$ sodium deoxycholate, $150 \mathrm{mM} \mathrm{NaCl}, 1 \mu \mathrm{g} / \mathrm{ml}$ aprotinin, leupeptin, pepstatin, $1 \mathrm{mM} \mathrm{Na}_{3} \mathrm{VO}_{4}$, $1 \mathrm{mM} \mathrm{NaF}$ ) for $30 \mathrm{~min}$ on ice and centrifuged at $14000 \times \mathrm{g}$ for $20 \mathrm{~min}$ at $4^{\circ} \mathrm{C}$. Protein concentration was determined by a modified Bradford method, using the Bio-Rad protein assay and compared with BSA standard curve. Cytosolic proteins $(2 \mu \mathrm{g})$ were separated by SDS-PAGE, electrotransferred to nitrocellulose and reacted with the different antibody. Blots were then developed using enhanced chemiluminescence detection reagents (SuperSignal West Pico, Pierce) and exposed to X-ray film.

All films were scanned by using Adobe photoshop software.

Two-dimensional gel electrophoresis. $\mathrm{H} 1355$ cells were homogenized in $20 \mathrm{mM}$ Tris- $\mathrm{HCl} \mathrm{pH} 7.8$ containing $1 \mu \mathrm{g} / \mathrm{ml}$ aprotinin, leupeptin and pepstatin. Cell extract $(150-300 \mu \mathrm{g})$ was diluted in $125 \mu \mathrm{l}$ of rehydration solution and applied to IPG Strip $7 \mathrm{~cm}, \mathrm{pH} 3-10$, for $12 \mathrm{~h}$ by using the rehydration loading method (Amersham). Proteins were then focused for up to $15000 \mathrm{Vh}$ at a maximum voltage of $5000 \mathrm{~V}$. After the first dimension, the strip was placed in equilibration solution $(6 \mathrm{M}$ urea, $2 \%$ SDS, $30 \%$ glycerol, $50 \mathrm{mM}$ Tris- $\mathrm{HCl} \mathrm{pH} \mathrm{8.8)} \mathrm{containing} 1 \%$ DTT for $10 \mathrm{~min}$ and then in the same buffer containing $2.5 \%$ iodacetamide for $5 \mathrm{~min}$. After equilibration, strip was loaded on $12 \%$ SDS-PAGE for the second dimension. Proteins were detected by Western blotting.

Immunoprecipitation. Total protein extracts $(500 \mu \mathrm{g})$ were subjected to immunoprecipitation with $2 \mu \mathrm{g}$ of anti-eEF-1A, or $2 \mu \mathrm{g}$ of anti-C-Raf for $16 \mathrm{~h}$ at $4^{\circ} \mathrm{C}$. Immune complexes were collected with $20 \mu$ of protein A-agarose for $2 \mathrm{~h}$ at $4^{\circ} \mathrm{C}$. The protein A-agarose/immune complex was washed four times with cold PBS, resuspended in $30 \mu \mathrm{l}$ of SDS-loading buffer, heated to $95^{\circ} \mathrm{C}$ for $5 \mathrm{~min}$ and used for Western blot analysis using anti-C-Raf, anti-eEF-1A, anti-phosphoserine, antiphosphothreonine and anti-ubiquitin.

SiRNA. SiRNAs were designed according to MWG Biotech software and synthesized by Dharmacom Research Inc. The sense sequences were: siRNA1, 5'AUG CGG UGG CAU CGA CAA AdTdT; siRNA2, 5'-AAG CAG UGG ACA AGA AGG CdTdT. The RNA oligonucleotides were used according to manufacturer's protocol. RNA scramble ready to use was also purchased from Dharmacom.

Cell transfection. Cells ( $150000 /$ well) were seeded into six-well plates $24 \mathrm{~h}$ before transfection in RPMl1640 antibiotics free $(2 \mathrm{ml})$ and then transfected with $100 \mathrm{nM}$ siRNA by using Lipofectamine 2000 (LF2000) according to the manufacturer's instructions (Invitrogen). After 24, 48 and $72 \mathrm{~h}$ of incubation, the cells were used for Western blot analysis. Cytofluorimetric analysis was performed by using 30000 cells/well. After $72 \mathrm{~h}$ from transfection, the medium was replaced, and the cells were exposed to $2500 \mathrm{IU} / \mathrm{ml}$ IFN $\alpha$ for $48 \mathrm{~h}$. Cells were then collected for FACS analysis.

Analysis of annexin $\mathbf{V}$ binding. Labelling of apoptotic cells was performed using an Annexin-V kit as described by the manufacturer (MedSystem Diagnostic). Analysis of apoptotic cells was performed by flow cytometry (FACScan, Becton 
Dickinson). For each sample, $2 \times 10^{4}$ events were acquired. Analysis was carried out by triplicate determination in at least three separate experiments.

FACS Analysis of eEF-1A expression. For EF-1A detection, cells were fixed with $3 \%$ paraformaldehide in PBS solution for $30 \mathrm{~min}$ at RT and permeabilized with $0.5 \%$ Tween 20 in PBS for $5 \mathrm{~min}$. For the detection of EF-1A, the cells were exposed to anti-EF-1A mAb (1:1000) for $30 \mathrm{~min}$ at $4{ }^{\circ} \mathrm{C}$ and subsequently exposed to phycoerythrin-conjugated anti-mouse goat antiserum $(1: 500)$ for $30 \mathrm{~min}$ at $4^{\circ} \mathrm{C}$ After final washes, cells were examined by FACScan flow cytometer (FACScan, Becton Dickinson). For each sample, $2 \times 10^{4}$ events were acquired. Analysis was carried out by triplicate determination on at least three separate experiments.

Immunofluorescence detection of eEF-1A and C-Raf. H1355 cance cells were seeded into $35 \mathrm{~mm}$ culture dishes on sterile coverslips and allowed to attach for $24 \mathrm{~h}$. Subsequently, the cells were incubated for $10 \mathrm{~min}$ in the presence of IFN $\alpha$ as described above. The medium was then removed, cells were washed with PBS and fixed with $1 \mathrm{ml} \mathrm{Cytofix/cytoperm} \mathrm{(Pharmigen)} \mathrm{for} 45 \mathrm{~min}$ at $41^{\circ} \mathrm{C}$ Subsequently, the fixation buffer was removed, and cells were washed with $1 \mathrm{ml}$ of washing buffer. For visualization of eEF-1A and C-Raf, the cells were exposed to anti-eEF-1A mAb and anti-C-Raf rabbit antiserum for $10 \mathrm{~min}$ at $41^{\circ} \mathrm{C}$ and washed with washing buffer. Subsequently, the cells were exposed to both rhodamineconjugated anti-mouse rabbit antiserum and FITC-conjugated anti-rabbit goat antiserum for $10 \mathrm{~min}$ at $41^{\circ} \mathrm{C}$. After final washes, coverslips were mounted on the dishes using a $50 \%$ solution of glycerol in PBS. The cells were examined with the help of LEICA TCS SP2 confocal microscope.

Kinase assay. $\mathrm{H} 1355$ cell extracts were immunoprecipitated with anti-eEF-1A $\mathrm{mAb}$ as reported above. The immunocomplexes were then incubated at $30^{\circ} \mathrm{C}$ for $60 \mathrm{~min}$ in $30 \mu \mathrm{l}$ of $1 \times$ kinase buffer $(25 \mathrm{mM}$ glycerol-phosphate, $50 \mathrm{mM}$ Tris- $\mathrm{HCl}$ pH 7.5, $2 \mathrm{mM} \mathrm{DTT}, 10 \mathrm{mM} \mathrm{MgCl}_{2}, 25 \mu \mathrm{M}$ cold ATP) in the presence of recombinant Raf- 1 kinase and $5 \mu \mathrm{Ci}$ of ${ }^{32} \mathrm{P}-\gamma$-ATP (Amersham). The reaction was stopped by the addition of $10 \mu$ l loading buffer and separated by SDS-PAGE.

Computational methods. To obtain a 3D model of human eEF-1A, the eEF$1 \mathrm{~A}$ protein sequence ${ }^{32}$ (Swiss-Prot entry P68104) (http://swissmodel.expasy.org) was used as target ${ }^{33}$ and the crystallographic structure of archaeal EF-1A in complex with GDP from S. solfataricus was used as template ${ }^{34}$ (pdb entry: $\left.1 \mathrm{JNK}\right) .^{35}$ Atomic coordinates obtained from the SWISS-MODEL server were then used for molecular dynamic simulation at $300 \mathrm{~K}$. To improve the accuracy of the model, a 2 ns molecular dynamic simulation by GROMACS 3.2 package was performed using GROMACS software package 3.2 (www.gromacs.org) and with the GROMOS96 force-hfield. Water was modelled by simple point-charge (SPC) model. ${ }^{36}$

The protein model was solvated with water molecules in a periodic cubic box of $10.5 \mathrm{~nm}$. The SHAKE algorithm was used to constrain all bond lengths. ${ }^{37}$ The Berendsen algorithm was used for the temperature control ${ }^{38}$, and the long-range electrostatic interactions were treated with the particle-mesh Ewald method. ${ }^{39}$ The atomic coordinates for the final structure of eEF-1A model were stored in a pdb format file obtained by averaging the atomic positions relative to the last $1.0 \mathrm{~ns}$ of the trajectory. The RMSD of all protein atoms with respect to the crystal structure was calculated after least-squares fitting of atom positions to the crystal structure and subsequently, averaged over all atoms.

Serine and threonine phosphorylation consensus sites in human eEF-1A were searched at the NetPhos 2.0 server (http://www.cbs.dtu.dk/databases/PhosphoBase/ ), on the basis of phosphorylation sequences collection data. ${ }^{23}$ The secondary structure and solvent accessibility data were extracted from the eEF-1A model after dynamic simulation by running appropriate scripts in DeepViewer SPDBV software. ${ }^{40}$

Statistical analysis. All data are expressed as mean \pm S.D. Statistical analysis was performed by analysis of variance (ANOVA) with Neumann-Keul's multiple comparison or Kolmogorov-Smirnov test where appropriate.

Acknowledgements. This work was partially supported by PRIN 2003 (MIUR Rome) to AA and PA and by Associazione Italiana Ricerca sul Cancro (AIRC) and Italian Ministry of Health FSN2006 to MC and FSN 2005 to AB. We thank Mark J Lynch, PhD, Principal Research Scientist, Department of Cancer Research, Bayer Pharmaceuticals, West Haven, Connecticut for supplying BAY 43-9006 and for careful reading of the manuscript. eEF-1A cDNA was kindly provided by $\mathrm{Dr} S$
Nagata (Osaka University Medical School). Wild type and K48R ubiquitin plasmids were kindly provided by Dr Michael Clague (University of Liverpool, UK). We thank Dr Salvatore Improta for his useful technical assistance.

1. Rhoads RE. Signal transduction pathways that regulate eukaryotic protein synthesis. J Biol Chem 1999; 274: 30337-30340.

2. Caraglia M, Budillon A, Vitale G, Lupoli G, Tagliaferri P, Abbruzzese A. Modulation of molecular mechanisms involved in protein synthesis machinery as a new tool for control of cell proliferation. Eur J Biochem 2000; 267: 3919-3936.

3. Lamberti A, Caraglia M, Longo O, Marra M, Abbruzzese A, Arcari P. The translation elongation factor $1 \mathrm{~A}$ in tumorigenesis, signal transduction and apoptosis. Amino Acids 2004; 26: 443-448

4. Moldave K. Eukaryotic protein synthesis. Ann Rev Biochem 1985; 54: 1109-1149.

5. Kaziro $\mathrm{Y}$, Itoh $\mathrm{H}$, Kozasa $\mathrm{T}$, Nakafuku M, Satoh T. Structure and function of signaltransducing GTP-binding proteins. Annu Rev Biochem 1991; 60: 349-400.

6. Lee S, Francoeur A-M, Liu S, Wang E. Tissue-specific expression in mammalian brain, heart, and muscle of $S 1$, a member of the elongation factor-1 alpha gene family. $J$ Biol Chem 1992; 267: 24064-24068.

7. Lee S, An DK, Wang E. Cloning of human and mouse brain cDNAs coding for S1, the second member of the mammalian elongation factor-1 alpha gene family: analysis of a possible evolutionary pathway. Biochim Biophys Res Commun 1994; 203: 1371-1377.

8. Knudsen SM, Fraydenberg J, Calrk BFC, Leffers $H$. Tissue-dependent variation in the expression of elongation factor-1 alpha isoforms: isolation and characterisation of a cDNA encoding a novel variant of human elongation-factor 1 alpha. Eur J Biochem 1993; 215: 549-554.

9. Zao-zhong S, Goldstein NI, Fisher PB. Antisense inhibition of the PTI-1 oncogene reverses cancer phenotypes. Proc Natl Acad Sci USA 1998; 95: 1764-1769.

10. Chuang SM, Chen L, Lambertson D, Anand M, Goss Kinzy T, Madura K. Proteasomemediated degradation of co-translationally damaged proteins involves translation elongation factor 1A. Mol Cell Biol 2005; 25: 403-413.

11. Kato MV, Sato H, Nagayoshi M, Ikawa Y. Upregulation of the elongation factor-1alpha gene by p53 in association with death of an erythroleukemic cell line. Blood 1997; 90: 1373-1378.

12. Kato MV. The mechanisms of death of an erythroleukemic cell line by p53: involvement of the microtubule and mitochondria. Leuk Lymph 1999; 33: 181-186.

13. Duttaroy A, Bourbeau D, Wang XL, Wang E. Apoptosis rate can be accelerated or decelerated by overexpression or reduction of the level of elongation factor- $1 \alpha$. Exp Cell Res 1998; 238: 168-176.

14. Chen E, Proestou G, Bourbeau D, Wang E. Rapid up-regulation of peptide elongation factor EF-1 $\alpha$ protein levels in an immediate early event during oxidative stress-induced apoptosis. Exp Cell Res 2000; 259: 140-148.

15. Ruest L-B, Marcotte R, Wang G. Peptide elongation factor eEF1A-2/S1 expression in cultured differentiated myotubes and its protective effect against caspase-3-mediated apoptosis. J Biol Chem 2002; 277: 5418-5425.

16. Talapatra S, Wagner JD, Thompson CB. Elongation factor-1 alpha is a selective regulato of growth factor withdrawal and ER stress-induced apoptosis. Cell Death Differ 2002; 9: 856-861.

17. Lee JM. The role of protein elongation factor eEF-1A2 in ovarian cancer. Reprod Biol Endocrinol 2003; 1: 69.

18. Caraglia M, Abbruzzese A, Leardi A, Pepe S, Budillon A, Baldassare G et al. Interferon- $\alpha$ induces apoptosis in human KB cells through a stress-dependent mitogen activated protein kinase pathway that is antagonized by epidermal growth factor. Cell Death Differ 1999; 6 : 773-780.

19. Caraglia M, Tagliaferri P, Marra M, Giuberti G, Budillon A, Di Gennaro E et al. EGF activates an inducible survival response via the RAS $\rightarrow$ Erk-1/2 pathway to counteract interferon $\alpha$-mediated apoptosis in epidermoid cancer cells. Cell Death Differ 2003; 10: 218-229.

20. Caraglia M, Vitale G, Marra M, Budillon A, Tagliaferri P, Abbruzzese A. Alpha-interferon and its effects on signalling pathways within cells. Curr Protein Pept Sci 2004; 5: 475-485.

21. Caraglia M, Marra M, Pelaia G, Maselli R, Caputi M, Marsico SA et al. Alpha-interferon and its effects on signal transduction pathways. J Cell Physiol 2005; 202: 323-335.

22. Bruzzese F, Di Gennaro E, Avallone A, Pepe S, Arra C, Caraglia M et al. Synergistic antitumor activity of EGF-R tyrosine kinase inhibitor Gefitinib (Iressa ${ }^{\mathrm{TM}}$ ) and IFN $\alpha$ in Head and Neck cancer cells in vitro and in vivo. Clin Cancer Res 2006; 15: 617-625.

23. Kreegipuu A, Blom N, Brunak S, Jarv J. Statistical analysis of protein kinase specificity determinants. FEBS Lett 1998; 430: 45-50.

24. Caldas TD, El Yaagoubi A, Richarme G. Chaperone properties of bacterial elongation factor EF-Tu. J Biol Chem 1998; 273: 11478-11482.

25. Esposito C, Marra M, Giuberti G, D'Alessandro AM, Porta R, Cozzolino A et al. Ubiquitination of tissue transglutaminase is modulated by interferon alpha in human lung cancer cells. Biochem J 2003; 15: 205-212.

26. Arcari P, Gallo M, lanniciello G, Dello Russo A, Bocchini V. The nucleotide sequence of the gene encoding the elongation factor 1a in Sulfolobus solfataricus Homology of the product with related proteins. Biochim Biophys Acta 1994; 1217: 333-337.

27. Caraglia M, Marra M, Budillon A, Meo G, Ricciardiello F, Bismuto E et al. Chemotherapy regimen GOLF induces apoptosis in colon cancer cells through multi-chaperone complex 
inactivation and increased Raf-1 ubiquitin-dependent degradation. Cancer Biol Ther 2005; 4: 1159-1167.

28. Khalyfa A, Carlson BM, Carlson JA, Wang E. Toxin injury-dependent switched expression between EF-1 alpha and its sister, S1, in rat skeletal muscle. Dev Dyn 1999; 216: 267-273.

29. Tsirigotis M, Zhang M, Chiu RK, Wouters BG, Gray DA. Sensitivity of mammalian cells expressing mutant ubiquitin to protein-damaging agents. J Biol Chem 2001; 276: 46073-46078.

30. Arcari $P$, Martinelli R, Salvatore F. The complete sequence of a full length cDNA for human liver glyceraldehyde-3-phosphate dehydrogenase: evidence for multiple mRNA species. Nucleic Acids Res 1984; 12: 9179-9189.

31. Maniatis T, Fritsch EF, Sambrook J (1982) Molecular Cloning, a Laboratory Manual. Cold Spring Harbour Laboratory: New York, pp 545.

32. Brands JHGM, Maasen JA, van Hemert FJ, Amons R, Moeller W. The primary structure of the alpha subunit of human elongation factor 1 structural aspects of the guaninenucleotide-binding site. Eur J Biochem 1986; 155: 167-171.

33. Bairoch A, Apweiler R. The SWISS-PROT protein sequence data bank and its supplement TrEMBL in 1999. Nucleic Acids Res 1999; 27: 49-54.
34. Vitagliano L, Masullo M, Sica F, Zagari A, Bocchini V. The crystal structure of Sulfolobus solfataricus elongation factor $1 \mathrm{~A}$ in complex with GDP reveals novel features in nucleotide binding and exchange. EMBO J 2001; 19: 53055311.

35. Westbrook J, Feng Z, Chen L, Yang H, Barman HM. The Protein Data Bank and structural genomics. Nucleic Acids Res 2003; 31: 489-491.

36. Berendsen HJC, Postma JPM, van Gunsteren WF, Hermans J. Intermolecular Forces Reidel. Dordrecht: The Netherlands, 1981.

37. Miyamoto S, Kollman PA. SETTLE: an analytical version of the SHAKE and RATTLE algorithms for rigid water models. J Comp Chem 1992; 13: 952-962.

38. Berendsen HJC, Postma JPM, Di Nola A, Haak JR. Molecular dynamics with coupling to an external bath. J Chem Phys 1984; 81: 3684-3690.

39. Darden T, York D, Pedersen L. Particle mesh Ewald: An N-log(N) method for Ewald sums in large systems. J Chem Phys 1993; 98: 10089-10092.

40. Guex N, Peitsch MC. SWISS-MODEL, and the Swiss-Pdb Viewer: an environment for comparative protein modeling. Electrophoresis 1997; 18: 2714-2723.

Supplementary Information accompanies the paper on Cell Death and Differentiation website (http://www.nature.com/cdd) 